\title{
Elephants and War in Zimbabwe
}

John B. Hallagan

After nearly ten years of civil war Zimbabwe now has more elephants than at any time since at least the 1940s: the bush was simply too dangerous for the poachers. Much wildlife management too had to be suspended during the war. Now in the Wankie National Park there is considerable elephant damage as a result of the population pressure, and some culling has been done.

In November 1980 I was able to spend several weeks in Zimbabwe and can report that, in spite of war and political upheaval, wildlife, especially elephants, is doing quite well. Zimbabwe presents a bright portrait of success in what is too often viewed as the dark future of wildlife conservation in Africa.

The war in Rhodesia, which began in earnest in 1972 and ended in April 1980 with the formation of the independent nation of Zimbabwe, was fought mainly in the bush in some of Zimbabwe's prime wildlife habitat. One of the unexpected benefits was a decline in wildlife poaching. Poachers stayed out of the bush because of the danger of attack by government or guerrilla forces. The war also precluded management in many areas, and wildlife populations, particularly elephants, have exceeded carrying capacity in some parts. Dr G.F.T. Child, Director of the Zimbabwe Department of National Parks and Wildlife Management, and Dr D.H.M. Cumming, Director of Research in the Department, both believe that there have never been more elephants Loxodonta $a$. africana in Zimbabwe than there are now. Dr Child has done extensive research to establish historical elephant densities in Zimbabwe. He has examined the records of Pretorious and other early explorers as well as the records of the hunters involved in the game eliminations of the 1930s and 1940s for tsetse fly control. None indicates elephant populations anywhere near the densities today. Dr Child has hypothesised that there were between 10,000 and 13,000 elephants throughout Zimbabwe in the 1940s; Dr Cumming estimates the total minimum population today at 43,000 elephants in seven distinct habitat areas. Dr Child noted that immigration from Zambia and Mozambique in the middle 1900 s probably contributed to the overall increase, combined with Zimbabwe's plentiful habitat and low hunting pressure. The estimates are based on extensive aerial surveys in 1979 and 1980 , supplemented with field observations. The established management policy in Zimbabwe is to maintain the determined ecological integrity of each ecosystem - a common policy goal throughout Africa that is rarely achieved. For elephants, Zimbabwe's wildlife

Above: An elephant band in the Sengwa Wildlife Research Area. 
managers have taken steps to achieve this goal, with population and behaviour studies, vegetation surveys and, when necessary, culling programmes.

Although Zimbabwe will face the ubiquitous problem of loss of elephant habitat for development, the problems may be less severe than in Uganda, South Africa, Rwanda and Kenya. Integrated land-use plans are being developed in conjunction with evaluations of the most equitable and efficient uses of Parks and Wild Life lands. An impressive 15 per cent of Zimbabwe's land area is in National Parks and Wild Life lands, which includes safari areas, wildlife research areas, recreational parks, sanctuaries, botanical parks and forestry lands. Sport hunting is allowed in the safari areas under a species quota system established by the Department, which sells licences on tender to professional hunting safari companies who then arrange their clients' safaris. Revenue from licence sale is transferred into the general government fund which prevents the Department receiving the direct financial benefits of sport hunting. Like many African wildlife departments, the Zimbabwe Department finds itself strapped for funds. For the past eight years its annual operating budget has been between 3.5 and 4 million dollars, which, given the large area, is inadequate. Dr Child estimates that the average price for an elephant hunting licence is approximately $\$ 3000$, which indicates that substantial revenue could be produced just from the sale of permits to hunt elephant.

Nearly half the land ( 45 per cent) is in Tribal Trust Lands and reserved for development by native Zimbabweans, and 40 per cent is privately owned and generally used for commercial farming. The largest elephant populations are in national parks and safari areas which afford optimum management potential. The largest single population inhabits the Wankie National Park area; a census in 1980 produced an estimate of 15,000 elephants in Wankie's $1,465,100$ hectares, and some observers have ventured estimates as high as 20,000. Several researchers believe that nearly 1000 elephants should be culled in Wankie in 1981 to maintain the park's ecological integrity, but no plans have been made as of this writing. A population estimated at 11,000 inhabits the Sebungwe region of north-central Zimbabwe which includes Chizarira National Park, Chirisa Safari Area, and the Sengwa Wild Life Research Area.

In the Sengwa Wild Life Research Area, a 373-sq-km section of wilderness at the southern end of the Chirisa Safari Area, the Hostes Nicolle Research Station is the base for several elephant research projects and promises to become one of the premier wildlife research stations in Africa. Elephant management in Sengwa exemplifies Zimbabwe's policy as a whole. After extensive research on the Sengwa elephants and their effects on the ecosystem, it was decided in 1980 to cull 392 to alleviate the severe destruction of botanical communities including Mopane and Brachystegia woodlands; areas that were once closed-canopy forest had been altered to open grassland and scrub primarily by elephant over-browsing. Dr Rowan Martin, who did much of the population census work, estimated about 2000 elephants in the Sengwa area at the beginning of the cull; after it almost the same number were found, a comment on the difficulties of aerial counts in dense bush. In order to facilitate the culling of the entire family groups as opposed to random shooting, Dr Martin made an exhaustive profile of the social structure of the elephant kin groups in Sengwa.

In 1978 Zimbabwe implemented an excellent system for regulating its ivory trade, both internally and for export. All ivory from culls and sportsmen's 


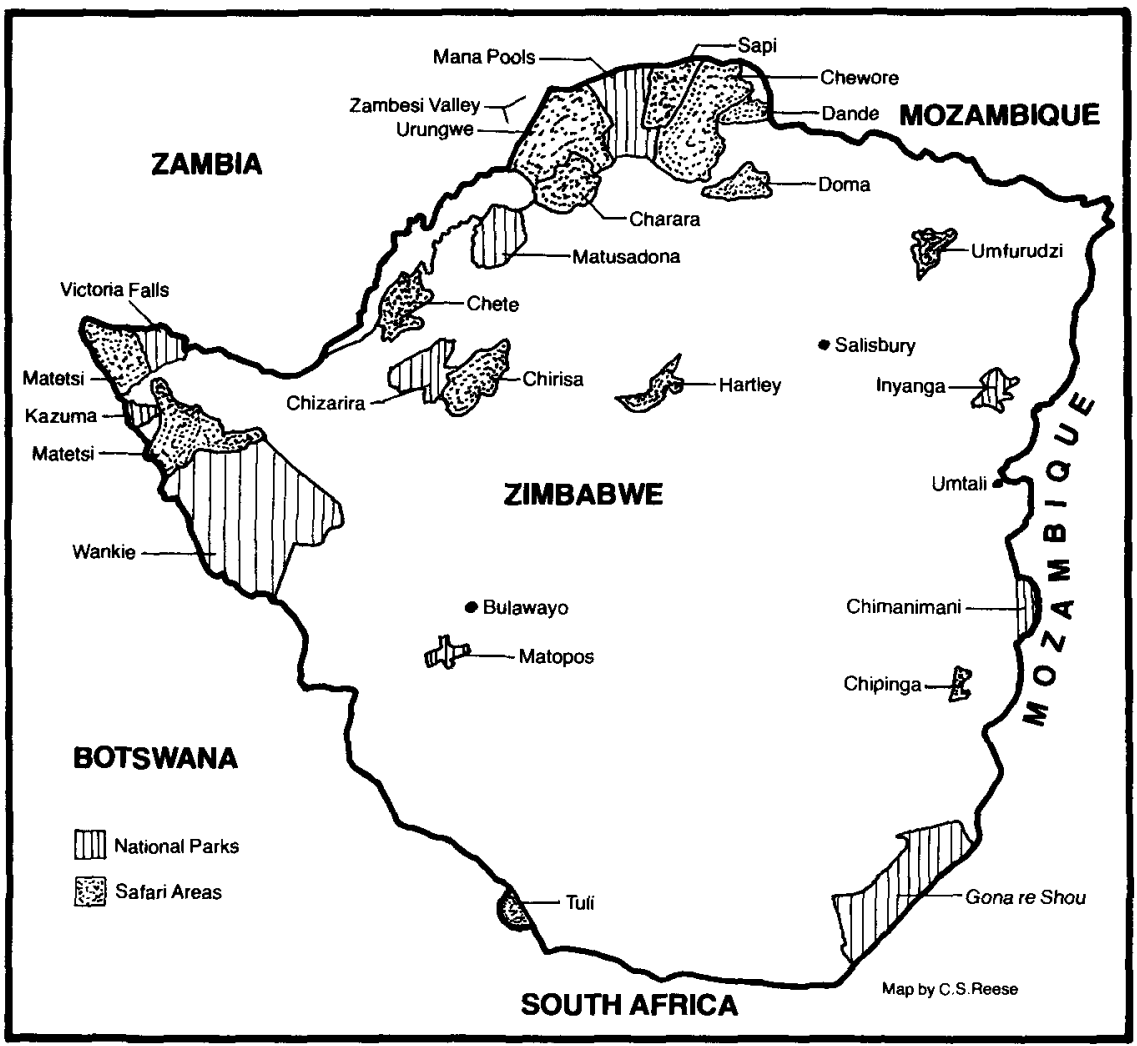

trophies must be registered with the Department of National Parks and Wild Life Management in Salisbury. The tusks are stamped with a registration number and are assigned a certificate of registration bearing the tusks' numbers, their weights and lengths. When a tusk is sold its certificate must be transferred with it and subsequently serves as a certificate of origin. Periodically the Department sells off its accumulated ivory stocks at public auctions, the proceeds going into the general government fund. Zimbabwe imports very little ivory from other African nations, and most of the ivory produced is exported or consumed internally. During the war much of the ivory produced was sold to South African business firms since economic sanctions by western nations and logistical problems precluded sale elsewhere. Zimbabwe has now expressed its desire to become a member of CITES, the Convention on International Trade in Endangered Species of Wild Fauna and Flora, ratification of which will allow Zimbabwe to enter the mainstream of international wildlife conservation activities and assist in the regulation of its ivory trade.

The Zimbabwe Department of National Parks and Wild Life Management faces complex problems in both the short and long term. This year they must make a decision on an elephant culling programme for Wankie National Park and other areas of high elephant densities; delay will simply postpone the inevitable and run the risk of severe damage to plant communities as in Sengwa. The end of the war has made the bush safer, opening it once again to poachers, and already park personnel have noticed an increase in poaching, 
primarily for antelope species on a subsistence level. Some elephant poaching has been noted, particularly along the border with Botswana near Wankie where two park rangers were killed by poachers in July 1980 . According to $\mathrm{Dr}$ Child, elephant poaching in Zimbabwe has traditionally been much less than in East Africa for several reasons, one being the low elephant numbers in the past. Another major factor is the lack of a well developed system for ivory sales and distribution; without the complex and efficient 'middleman' systems of East Africa export out of Zimbabwe is difficult.

The staff of the Department have built up one of the finest departments in Africa, and although the future appears difficult they are clearly capable. Barring major political changes, the Department should continue to administer one of the best elephant conservation programmes in Africa.

John B. Hallagan, 16 Sutherland Street, Pittsford, NY 14534.

\section{Giraffes and Elephants in the Desert}

A small population of giraffes has adapted to living in the Namib Desert areas of Kaokaland, in arid desert conditions. In 1934 numbers were about 200; in 1977 surveys suggested 50-60 in western Kaokaland and about 20 in the south-east. Human disturbance now threatens the survival of these small groups. Four-wheel drive vehicles are sometimes used to chase giraffes, which can be lethal in the desert heat. P.J. Vilgoen writing in African Wildlife, urges the importance of studying them to find out why they prefer the desert, and how they survive.

The Kaokaland desert also supports a group of elephants, thought now to number $50-80$ (600 to 1000 in 1934) which are now being studied to find out how they can best be conserved. They are said to have relatively slender legs and huge feet to help desert travel - some cross $45 \mathrm{~km}$ of desert from the acacias in the usually dry riverbeds, on which they browse, to the nearest water. They also at times dig in the riverbeds for water, and thus make water available for other animals.

\section{Puffin Increase - and Decrease}

'The general state of puffindom is far better than at any time this century', says Dr M.P. Harris reviewing the status of Fratercula arctica in the BTO News. Numbers have increased substantially since 1970 when the BTO described the species as 'in peril' notably on the Isle of May, where, swelled by immigration from the Farne Islands, the population has been increasing recently at 22 per cent a year.

Most colonies, however, are stable, 'in marked contrast to the depressing picture in the first half of the century'. The declining colonies now are mainly on the south coast of England and in France, the southern edge of the puffin's range. Puffins are a cold-water loving species.

At the same time from northern Norway comes news, reported by Stephen Mills in the New Scientist, that nearly every puffin chick - half a million of them - in one of the world's largest breeding colonies, the island of Rost, died last summer through shortage of food - herring, sprats and sand eels - due to overfishing. Catches have been reduced but so far with little effect. Thanks to their long lifespan (25 years) and low adult mortality, puffins remain on Rost, but a crash is inevitable unless fish stocks rebuild.

\section{Small Expeditions}

The Expedition Advisory Centre is holding seminars on 'Planning a Small Expedition' in London, November 6, Malvern Nov. 21, Edinburgh Nov. 26, and Leeds Nov. 28. Information on request to 1 Kensington Gore, London SW7 2AR. 